\title{
Pengaruh Pembelajaran Daring terhadap Peningkatan Nilai Siswa Kelas X di SMK Ma'arif 9 Kebumen
}

\author{
Mufid Rozikin $^{1]}$, Sulimei Sari ${ }^{2]}$, Suratno $^{3]}$, Soviyana Nurhayati ${ }^{4]}$ \\ Politeknik Dharma Patria Kebumen \\ E-mail: ${ }^{1]}$ mufidrozikin25@gmail.com \\ ${ }^{2]}$ sulimeisari08@gmail.com \\ ${ }^{3]}$ suratno26@ymail.com \\ ${ }^{4]}$ soviyananurhayati@gmail.com
}

\begin{abstract}
Abstrak
Covid-19 memiliki dampak yang cukup signifikan dalam kehidupan masyarakat pada saat ini, salah satunya dalam bidang pendidikan. Pembelajaran yang seharusnya dilakukan secara tatap muka harus ditiadakan dan digantikan dengan pembelajaran daring. Saat ini pembelajaran daring menjadi sarana alternatif bagi tenaga pendidik agar kegiatan belajar mengajar tetap berjalan meskipun siswa sedang berada di rumah. Pembelajaran daring memiliki sisi positif dan sisi negatif, bagi siswa dampak negatifnya yaitu siswa kurang optimal dalam menguasai materi yang disampaikan guru sehingga membuat nilai para siswa menjadi turun. Penelitian ini bertujuan untuk mengetahui nilai rata - rata kelas X sebelum pandemi Covid-19 dan sesudah pandemi Covid-19 di SMK Ma'arif 9 Kebumen, serta untuk mengetahui kendala apa saja yang diraskan guru maupun siswa dalam melaksanakan pembelajaran daring selama masa pandemi Covid19. Metode yang digunakan dalam penelitian ini adalah penelitian deskrtiptif dengan pendekatan kualitatif. Penelitian ini telah dilakukan pada tanggal 25 Januari sampai 2 Maret 2021 Tahun Ajaran 2020/2021 di SMK Ma'arif 9 Kebumen. Sampel penelitian ini terdiri dari satu kelas. Penentuan sample dengan menggunakan teknik sampling purposive. Hasil penelitian menunjukan bahwa dalam pembelajaran daring di SMK Maarif 9 Kebumen Nilai Rata-rata sebelum pandemi 86,92 dan sesudah pandemi 84,38 ,sehingga terjadi selisih penurunan nilai sebesar 2,54. Sehingga dapat disimpulkan bahwa dalam pembelajaran daring mempengaruhi penurunan nilai rata-rata kelas sebesar $3,01 \%$ jika dibandingkan dengan nilai sebelum pandemi.
\end{abstract}

Kata kunci: Nilai Rata-Rata, Deskriptif, Penurunan Nilai

\section{The Effect of Online Learning the Grades of Student in Class $X$ at Vocational High School Ma'arif 9 Kebumen}

\begin{abstract}
Covid-19 has a significant impact on people's lives today, one of which is in the field of education. Learning that should be done face-to-face must be abolished and replaced with online learning. Currently online learning has become an alternative means for educators so that teaching and learning activities can continue even though students are at home. Online learning has a positive side and a negative side, for students the
\end{abstract}


negative impact. The purpose of this study was to find out the average score of the class before the pandemic and after the pandemic at Maarif 9 Kebumen Vocational High School, and to find out what obstacles are felt by teachers and students in carrying out bold learning during the Covid-19 pandemic. The method used in this study is descriptive research with qualitative approach.This research was conducted from January 25 to March 2, 2021 for the 2020/2021 academic year at Maarif 9 Kebumen High School.The sample of this study consisted of one class.Determination of the sample using purposive sampling technique.The results showed that in online learning at SMK Ma'arif 9 Kebumen the average score before the pandemic was 86.92 and after the pandemic was 84.38, so there was a difference in grades of 2.54. So it can be concluded that online learning affects the decrease in the class average score of $3.01 \%$ when compared to the value before the pandemic.

Keywords: Average Score, Descriptive, Decrease of Score

\section{PENDAHULUAN}

Virus Corona atau yang biasa disebut juga dengan Covid-19 pertama kali ditemukan di negara China lebih tepatnya di Kota Wuhan. Sudah banyak negara yang melaporkan adanya penularan virus corona (yunita,2020). Pandemi Covid-19 termasuk musibah yang sangat meresahkan bagi seluruh penduduk manusia di dunia, karena sangat mengacaukan bidang perekonomian dan pendidikaan. Seluruh kehidupan manusia di dunia sangat terganggu dengan adanya virus yang sangat mematikan ini, tanpa terkecuali dalam bidang pendidikan. Adanya Pandemi Covid-19 ini banyak negara yang menutup sekolah, perguruan tinggi maupun universitas untuk menghindari penularan virus Covid-19, Indonesia pun melakukan hal yang sama dengan negara lainnya. Penyebaran virus corona pada awalnya menunjukan dampak pada bidang ekonomi yang mulai lesu, dan kemudian pada saat ini juga dirasakan dalam bidang pendidikan. Dengan adanya Covid-19 ini banyak negara mengeluarkan kebijakan yaitu dengan meliburkan sekolah selama masa pandemi Covid19, Negara Indonesia juga meliburkan segala aktivitas pendidikan Membuat pemerintah dan lembaga terkait membuat alternatif supaya pendidikan tetap berjalan seperti biasanya. Adanya pandemi Covid-19 di Indonesia maupun dunia, menjadikan sistim pembelajaran tatap muka diganti dengan pembelajaran sistem daring ataupun online,Dimana siswa tetap melakukan kegiatan belajar dari rumah masing-masing.

Pembelajaran daring merupakan sebuah inovasi dalam pendidikan karena telah melibatkan sebuah tekhnologi dalam proses pembelajaran. Pembelajaran daring dilakukan dengan memanfaatkan tekhnologi internet, dan dalam penyampaian materi maupun proses belajar mengajar dilakukan tanpa adanya tatap muka antara guru dengan siswa, dimana dalam penyampaian materi guru memberikan materi pembelajaran melalui Whatsapp, Email, Google Classroom, Google Meet, Zoom meet ataupun media lain nya.

Pembelajaran daring adalah pembelajaran yang di lakukan melalui jejaring web. Setiap mata pelajaran menyediakan materi dalam bentuk rekaman video atau slide show, dengan diberikan tugas mingguan yang harus dikerjakan dengan batas waktu yang telah ditentukan oleh guru mata 
pelajaran tersebut. Hadisi dan Muna, (2015:117-140) mendiskripsikan bahwa manfaat e-learning yaitu untuk mempermudah peserta didik dalam mengakses materi serta untuk mempermudah interaksi antara siswa dan guru pengampu mata pelajaran. Peserta didik juga bisa bertanya tentang materi yang belum di mengerti kepada guru tanpa harus bertatap muka secara langsung.

Adanya pembelajaran daring siswa diharapkan dapat memahami materi yang telah disampaikan oleh gurunya. Namun siswa cenderung menjadi kurang efektif dalam proses pembelajaran daring, karena dalam proses pembelajaran daring siswa menjadi kurang aktif dalam menyampaikan aspirasi dalam pemikirannya, sehingga dapat menjadikan pembelajaran yang menjenuhkan bagi setiap siswa. Oleh sebab itu perlu dilakukan motivasi untuk dapat meningkatkan nilai dan bisa semangat dalam proses belajar daring.

Pembelajaran daring memiliki dampak baik dan dampak yang kurang baik. Meskipun memiliki dampak baik masih ada beberapa orangtua tidak setuju diadakannya pembelajaran sistem daring karena tidak semua siswa memiliki kemampuan untuk cepat memahami materi apa yg disampaikan oleh para guru. Dampak baik yang dihasilkan dari pembelajaran daring adalah guru tetap bisa menyampaikan materi kepada siswanya dan mengurangi jumlah jumlah pandemi yang terjadi pada saat ini. Sedangkan dampak yang kurang baik yang dihasilkan oleh pembelajaran daring adalah bisa berdampak pada penurunan nilai bagi siswa karena siswa dituntut untuk memahami materi yang telah diberikan dari gurunya melalui media yang telah ditentukan dan sistem daring ini membuat siswa menjadi lebih mudah bosan dalam mengikuti pelajaran dan tidak semua guru atau tenaga pendidik bisa mengoperasikan aplikasi yang telah tersedia, karena hal tersebut bisa memperhambat guru dalam penyampaian materi.

Di tengah kedaruratan pandemic covid-19 ini yang melanda dunia khususnya di Negara Indonesia ,tidak ada pilihan lain selain menerapkan konsep pembelajaran secara daring ,menurut Hung et al (2010), ada beberapa cacatan yang harus diperhatikan agar pembelajaran daring tetap berjalan dengan optimal, yaitu dengan adanya penggunaan komputer/internet, pembelajaran secara mandiri ,pengendalian diri bagi setiap siswa,kepercayaan diri bagi siswa saat berkomunikasi melalui pembelajaran daring.

Semangat belajar bagi setiap siswa mempunyai pengaruh yang sangat penting pada pembelajaran daring, ini menunjukan bahwa setiap siswa harus menunjukan semangat yang tinggi pada setiap kegiatan pembelajaran daring sedang berlangsung. Pembelajaran daring memungkinkan siswa memiliki keluaasan waktu untuk mengerjakan tugas yang telah diberikan dari gurunya sehimgga dapat belajar kapanpun dan dimanapun.

Kendala yang dihadapi guru antara lain yaitu sulitnya mengukur kemampuan siswa terhadap materi satu dengan yang lain. Bahkan masih ada diantaranya beberapa siswa yang masih malas mengumpulkan tugas atau bahkan meminta bantuan orang lain dalam pengerjaan tugas yang diberikan. Didalam pembelajaran daring siswa wajib aktif bertanya karena hal ini menjadi salah satu cara untuk mendapatkan nilai yang lebih baik lagi. Dengan adanya proses pembelajaran daring siswa diharapkan harus tetap semangat dalam mengerjakan tugas 
yang telah diberikan oleh gurunya melalui media yang telah ditentukan.

Dalam hal ini siswa juga membutuhkan pendampingan langsung dari orang tua untuk melakukan pengawasan selama pembelajaran daring. Banyak orang tua yang kewalahan karena tak jarang masih ada siswa yang dalam pengumpulan tugas dibantu orang tua.

Berdasarkan fakta yang saya dapatkan di lapangan saat melakukan observasi terhadap siswa kelas $\mathrm{X}$ di Smk Ma'arif 9 Kebumen, saat melakukan pembelajaran daring masih banyak kendala terhadap siswa itu sendiri, karena siswa merasa kurang nyaman dalam memperoleh materi yang telah disampaikan oleh gurunya. Proses belajar yang monoton dan kurangnya interaksi siswa dengan guru nya membuat siswa menjadi bosan dan malas dalam memahami materi dalam pembelajaran daring.

Dalam pembelajaran daring, penting untuk ditambahkan pengarahan kepada orang tua dan peserta didik, tentang adanya wabah pandemi Covid19. Dengan begitu kita memperoleh materi yang sama seperti dengan pembelajaran offline atau tatap muka. Dan dengan adanya pembelajaran Online atau daring efeknya sangat bagus, programnya tepat sasaran pembelajaranya tercapai.

Hal ini karena adanya faktor lingkungan belajar yang membuat siswa itu nyaman dalam belajar daring, dan karakteristik setiap masing-masing peserta didik yang berbeda-beda. Pembelajaran daring disetiap sekolah menerapkan bentuk dan teknis yang berbeda-beda. Untuk outputnya, banyak juga siswa yang merasa kurang paham mengenai materi yang telah di sampaikan oleh gurunya. Dalam kegiatan Praktikum yang dilaksanakan secara online terkadang tidak bisa di praktekan dirumah masing-masing karena keterbatasan alat dan sampel percobaan. Guru pun lebih sulit untuk mengawasi siswa saat berlangsungnya pembelajaran daring karena terbatas pada media, sehingga mungkin ada siswa yang ketiduran saat guru menyampakan materi atau siswa hanya titip absensi saja tetapi dalam pembelajaran berlangsung tidak memperhatikannya. Selain itu masalah dalam pembelajaran daring ini adalah masih terbatasnya sinyal internet di beberapa daerah sehingga menghambat berlangsung nya proses pembelajaran.

Pembelajaran daring mempuyai sisi positif dan sisi negatif yang saling beriringan. Hal ini nantinya akan membawa konsekuensi seberapa efektifkah pembelajaran daring dimasa pandemi Covid-19 ini. Arti kata efektif menurut KBBI adalah ada efeknya, akibat, pengaruh atau membawa hasil guna. Oleh karena itu, tingkat keefektifanya bisa dikatakan relatif, tergantung dari masing-masing komponen yang menunjang atau turut serta dalam proses pembelajaran daring itu sehingga diharapkan pembelajaran daring ini membawa hasil yang terbaik meskipun dalam keterbatasan yang ada. Siswa diharapkan lebih aktif bertanya dalam proses belajar daing bukan hanya mengandalkan materi yang diberikan oleh guru saja, tetapi juga dari sumber lain misanya dari internet atau buku. Para guru dan pihak sekolah seharunya menyesuaikan kurikulum yang berlaku saat ini sehingga pembelajaran daring tetap dapat dilaksanakan dengan baik dan tidak terlalu membebani setiap siswa. Guru juga harus membuat model dan strategi penyampaian materi menjadi lebih mudah dan efektif bagi siswa agar siswa lebih mudah memahami materi dan tidak mudah bosan. Pemilihan media daring yang tepat juga menjadi poin yang sangat 
penting. Seperti pemanfaatan WhatsApp Grup yang paling mudah untuk diakses oleh siswa. Meskipun pembelajaran daring secara keseluruhan memberi kebebasan untuk mengakses materi di internet pembatasan aplikasi yang penggunaannya masih sulit diakses lebih baik di hindari. Kendala jaringan maupun kuota internet yang sering dikeluhkan siswa maupun dari pihak orangtua juga sering terdengar. Keberhasilan guru dalam mensukseskan pembelajaran daring salah satunya yaitu pemilihan aplikasi yang tepat untuk pembelajaran daring. Berinovasi dalam membuat materi juga harus semenarik mungkin. Kerjasama dari berbagai pihak antara pihak sekolah, guru, siswa maupun orangtua sangat diharapkan.

Adapun kendala yang masih ditemukan dalam pembelajaran daring yaitu belum adanya kesiapan baik secara sistem maupun secara teknis. Keterbatasan dari siswa dalam penggunaan teknologi juga masih ditemui.

Pemerintah juga diharapkan supaya mengusahakan yang terbaik untuk proses keberlangsungan pembelajaran di masa Pandemi Covid19 ini, seperti contoh pemberian kuota internet geratis bagi setiap siswa, dan guru supaya semua dapat mengikuti kegiatan pembelajaran melalui daring. Dalam jangka panjang, pembelajaran daring dapat membatasi proses kegiatan di lapangan atau praktikum yang mendukung mata pelajaran sehingga diperlukan inovasi pembelajaran campuran atau blended learning saat kondisi sudah mulai membaik dan memungkinkan pelaksanaan protokol kesehatan di sekolahan.

\section{METODE}

Metode penelitian adalah cara ilmiah untuk memperoleh data dengan maksud tertentu. Penelitian yang dilakukan ini mengunakan metode jenis penelitian deskriptif dengan pendekatan kualitatif.

Penelitian deskriptif adalah satu jenis penelitian yang bertujuan untuk memberikan suatu gambaran tentang suatu subjek/objek yang diteliti dengan apa adanya.

Sedangkan pendekatan kualitatif adalah pendekatan yang dilakukan secara utuh kepada subjek penelitian dalam setiap peristiwa. Dan hasilnya dapat diuraikan dalam sebuah kata yang tertulis secara umum.

Dalam metode ini penulis bermaksud untuk mengumpulkan data historis dan mengamati secara seksama tentang masalah yang sedang diteliti oleh penulis yang bertujuan untuk memperoleh data-data dalam menyusun laporan ini. Kemudian data tersebut dapat diolah untuk mendapatkan hasil atau kesimpulan mengenai masalah yang sedang diteliti.

Dalam metode ini penulis bermaksud untuk mengumpulkan data historis dan mengamati secara seksama tentang masalah yang sedang diteliti oleh penulis yang bertujuan untuk memperoleh data-data dalam menyusun laporan ini. Kemudian data tersebut dapat diolah untuk mendapatkan hasil atau kesimpulan mengenai masalah yang sedang diteliti.

Dalam penelitian ini, penulis langsung terjun ke SMK Maarif 9 kebumen yang beralamat di Jl.Raya Klirong-Kebumen untuk mencari informasi langsung yang mendalam terkait pelaksanaan pembelajaran daring atau online di masa Pandemi Covid -19 ini. Peneliti melakukan observasi langsung mengenai proses pembelajaran daring yang sedang berlangsung antara siswa dan guru.

Teknik Pengumpulan data yang digunakan dalam penelitian ini adalah:

1. Kepustakaan 


\begin{tabular}{|c|c|c|}
\hline Studi & Kepustakaan & yaitu \\
\hline melakukan & penelitian & dengan \\
\hline mempelajari & dan membaca & literatur \\
\hline $\begin{array}{l}\text { yang ada } \\
\text { permasalahan }\end{array}$ & hubungannya & \\
\hline dengan & enelitian. & yang \\
\hline 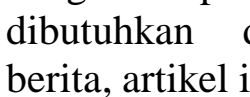 & $\begin{array}{l}\text { didapatkan } \\
\text { ilmiah, dan s }\end{array}$ & 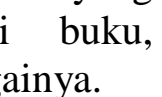 \\
\hline
\end{tabular}

Studi kepustakaan juga menjadi bagia penting dalam kegiatan penelitian ini,karena dapat memberikan informasi tentang proses pembelajaran daring yang berlangsung di SMK Ma'arif 9 Kebumen.

\section{Observasi}

Observasi atau pengamatan merupakan salah satu metode pengumpulan data atau informasi yang dilakukan dengan cara mengamati atau meninjau secara langsung dilokasi. Observasi sendiri dibedakan menjadi tiga jenis yaitu partisipatif, observasi terus terang ataupun observasi tersamar, observasi tidak berstruktur.

Dalam observasi atau pengamatan ini di usahakan mengamati kegiatan yang wajar dan yang sebenarnya tanpa adanya manipulasi data.Data observasi berupa deskripsi yang faktual, cermat, dan terperinci.

Selama penelitian berlangsung, peneliti berada diluar subyek (non partisipan), peneliti hanya sekedar mengamati dalam proses pembelajaran daring yang sedang berlangsung.

\section{Wawancara}

Wawancara adalah percakapan dengan maksud tertentu yang dilakukan oleh kedua belah pihak untuk mendapatkan informasi yang di butuhkan.Teknik ini dilakukan dengan cara melakukan komunikasi dengan pihak-pihak yang terkait dalam data dan fakta yang diperlukan untuk memperoleh informasi yang tepat, akurat dan terpercaya untuk mendukung ketetapan dan kemantapan narasumber.

Teknik wawancara yang digunakan dalam penelitian ini adalah wawancara bebas terpimpin, dimana pertanyaan yang di berikan tidak terpaku pada pedoman wawancara dan dapat diperdalam lagi maupun dikembangkan dalam berbagai situasi dan kondisi di lapangan. Dalam melakukan wawancara bebas terpimpin membutuhkan kreatifitas, karena peneliti harus benar-benar memiliki dasar yang kuat dalam melakukan wawancara tersebut.Kebebesan ini akan menggali kejujuran informan, terutama yang berhubungan dengan sikap, sehingga peneliti tidak merasa asing dan dicurigai.

Oleh kerena itu, dalam melakukan wawancara harus memilih waktu yang tepat, yang bertujuan agar informan berada pada waktu senggang (tidak sibuk), dan dalam kondisi yang santai, sehingga keterangan yang diberikan adalah benar tanpa mengadaada.

Informan dalam penelitian ini adalah Kepala sekolah Smk Ma'arif 9 Kebumen, Waka Kurikulum, Waka Kesiswaan, dan perwakilan siswa kelas $\mathrm{X}$.

\section{HASIL DAN PEMBAHASAN}

Munculnya pandemi Covid-19 ini mengubah pola kehidupan masyarakat diseluruh dunia tak terkecuali di Indonesia. Pada saat ini dengan munculnya Pandemi Covid-19 membuat pemerintah mengeluarkan peraturan larangan supaya masyarakat untuk tidak berkerumun. Hal ini mendorong pemerintah membuat kebijakan baru dalam dunia pendidikan, salah satunya adalah dengan meniadakannya kegiatan tatap muka di sekolah dan diliburkannya seluruh kegiatan yang ada di sekolah. Dengan 
adanya kebijakan tersebut pihak pemerintah menggantikan kegiatan belajar mengajar yang semula dilakukan secara tatap muka menjadi daring. Pelaksanaan pembelajaran daring tentunya berbeda dengan pembelajaran tatap muka. Suatu keharusan dalam pembelajaran daring harus mempersiapkan perangkat pendukung seperti laptop maupun handphone. Hal tersebut menjadi keresahan sendiri bagi siswa maupun orangtua. Masih cukup banyak dari pihak orangtua yang kurang setuju diadakannya pembelajaran melalui daring dikarenakan materi yang disampaikan oleh guru lebih sukar untuk dipahami oleh para siswa dan orangtua juga banyak yang "terpaksa" menjadi pengganti peran guru selama kegiatan belajar mengajar masih menggunakan sistem daring.

Untuk saat ini cara yang aman dalam upaya pencegahan Covid-19 yaitu hanya melalui sistem pembelajaran daring supaya memudahkan guru dalam menyampaikan segala jenis materi dan dalam pemberian tugas. Aplikasi yang digunakan untuk menyampaikan materi pada daring diantaranya yaitu WhatsApp, Zoom, Google Meet, Google Classroom, dan aplikasi sejenis lainnya. Untuk mengakses aplikasi tersebut dibutuhkan handphone android dan kuota yang memadai yang harus dimiliki setiap siswa.

Pembelajaran daring siswa tidak terkendala waktu dan tempat dimana siswa dapat mengikuti pembelajaran daring di rumah maupun dari tempat lain. Akan tetapi masih banyak siswa yang kesulitan dalam proses pembelajaran daring ini. Mulai dari bahan ajar yang ada sulit untuk dipahami serta metode penyampaian yang tidak secara langsung mempersulit siswa dalam setiap pengerjaan tugas yang diberikan oleh guru nya. Terlebih dengan keterbatasan teknologi yang di miliki siswa tidak jarang masih ada orang tua yang terbebani dengan harus memiliki handphone android untuk menunjak keikutsertaan si anak dalam proses pembelajaran daring ini. Kuota internet yang mahal juga menjadi beban tersendiri bagi siswa.

Pembelajaran daring dapat memberikan metode pembelajaran yang menarik dan efektif seperti adanya umpan baik yang efektif,serta menggabungkan kolaborasi menggabungkan belajar secara mandiri, serta pembelajaran yang menghasilkan keaktifan bagi setiap peserta didik.Pembelajaran daring merupakan kombinasi yang memadukan pembelajaran secara konvensional dengan tekhnologi informasi yang di tuangkan dalam website, sehingga peserta didik dapat untuk mengakses dan mengunduh materi secara bebas secara leluasa.

Istilah model pembelajaran daring atau Online Learning Model (OLM) melalui beberapa tahapan, pada tahapan pertama di gunakan sebagai gambaran system belajar menggunakan tekhnoligi internet yang berbasis computer.Tahap berikutnya fungsi computer telah digantikan oleh fungsi telepon seluler.Pembelajaran daring dapat berlangsung dengan luwes dan enak serta siswa dapat mengakses pembelajaran kapan saja.Kecepatan pembelajaran daring di sesuaikan dengan kecepatan belajar masingmasing siswa.

Mengatasi persoalan jarak dan waktu, pembelajaran daring dapat mengatasi hambatan jarak jauh dan waktu bisa di akses tanpa adanya kendala waktu, serta jangkauan yang lebih luas. Siswa yang mengikuti pembelajaran daring dapat menghemat waktu dan tenaga.Sehingga waktu dan tenaga yang tersisa dapat digunakan 
untuk hal-hal yang lainnya diluar jam pembelajaran daring.

Data Nilai Siswa kelas X SMK Ma'arif 9 Klirong Kebumen Sebelum Pandemi Covid-19.

Tabel 1. Sumber data sekolah sebelum pandemi covid-19

\begin{tabular}{|c|c|c|c|}
\hline No & NIS & Nama & $\begin{array}{l}\text { Nilai } \\
\text { Rata- } \\
\text { Rata }\end{array}$ \\
\hline 1 & 3673 & $\begin{array}{l}\text { Amanda Pradita } \\
\text { Nurul Febrianti }\end{array}$ & 89,10 \\
\hline 2 & 3674 & $\begin{array}{c}\text { Ambar } \\
\text { Rahmawati }\end{array}$ & 88,06 \\
\hline 3 & 3675 & Aminatul Afifah & 86,08 \\
\hline 4 & 3676 & $\begin{array}{l}\text { Anggie Maulina } \\
\text { Agustin }\end{array}$ & 90,00 \\
\hline 5 & 3677 & $\begin{array}{l}\text { Anti Malikhatus } \\
\text { Solikhah }\end{array}$ & 88,12 \\
\hline 6 & 3678 & Barrotuttaqiyyah & 84,58 \\
\hline 7 & 3679 & Catur Pangesti & 85,92 \\
\hline 8 & 3680 & Dede Lina & 87,34 \\
\hline 9 & 3681 & Desti Wulandari & 87,58 \\
\hline 10 & 3682 & Elma Alfi & 87,89 \\
\hline 11 & 3683 & $\begin{array}{l}\text { Faizatul } \\
\text { Khoeriyah }\end{array}$ & 86,61 \\
\hline 12 & 3684 & Faridatul Mufidah & 84,18 \\
\hline 13 & 3685 & $\begin{array}{l}\text { Farikhatus } \\
\text { Sholihah }\end{array}$ & 85,64 \\
\hline 14 & 3686 & Fitriyah Nur & 85,32 \\
\hline
\end{tabular}

Jannah

$$
\begin{array}{lrlr}
15 & 3687 & \text { Hani Fatmawati } & 86,59 \\
16 & 3688 & \begin{array}{l}
\text { Isnaeni Rahmah } \\
\text { Bidari }
\end{array} & 86,62
\end{array}
$$

$\begin{array}{lll}17 & 3689 & \begin{array}{l}\text { Khuswatun } \\ \text { Khasanah }\end{array}\end{array}$

$\begin{array}{lll}183690 & \begin{array}{l}\text { Lilis Miftakhul } \\ \text { Khoeriyah }\end{array}\end{array}$

$\begin{array}{lll}193691 & \begin{array}{l}\text { Nur Aeni } \\ \text { Laeliyah }\end{array} & 86,94\end{array}$

203692 Nur Fitria Rahma 89,51

213693 Nur Hidayati 83,76

223694 Nur Istiqomah 86,16

233695 Nur Wakhidah 87,04

$\begin{array}{lll}243696 & \begin{array}{l}\text { Ponisatin } \\ \text { Rahmawati } \quad 87,10\end{array}\end{array}$

253697 Priyanita Zahroh 88,53

263698 Rani Mundarsih 86,19

273699 Ratih Juwita 87,06

$\begin{array}{llll}28 & 3700 & \text { Resti Utami } & 86,91\end{array}$

293701 Rismawati $\quad 87,73$

$30 \quad 3702$ Rizqi Nurjannah $\quad 84,42$

313703 Rohmatul Inayah 87,40

$32 \quad 3704$ Septi Nur Vita

Septi Nur Vita
Sari $\quad 89,58$

Septi Riswati

Kasari $\quad 86,90$

Septi Umi

Salamah

90,06 


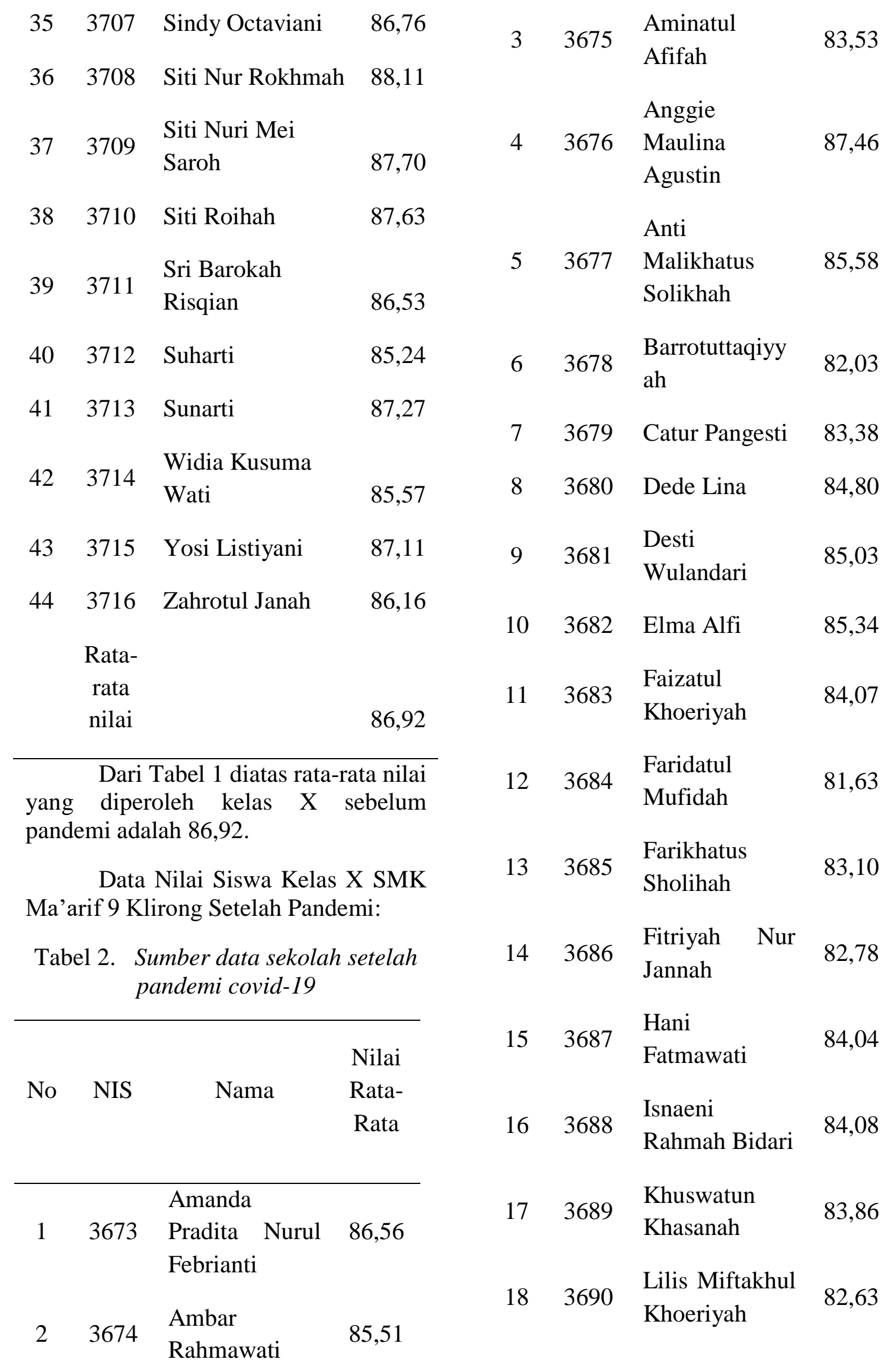




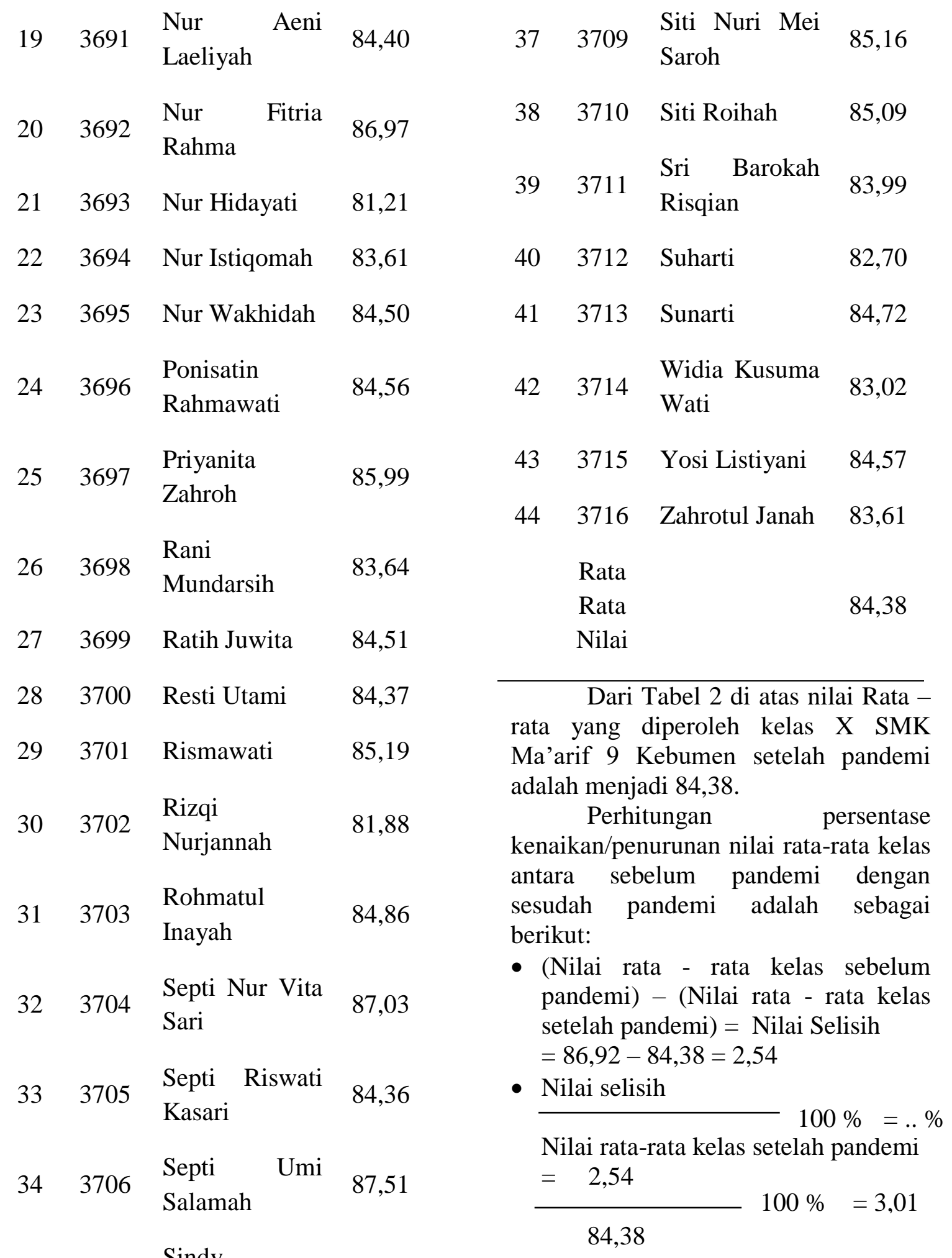

\section{Pembahasan}

Saat ini pembelajaran melalui daring cukup membantu para guru dalam menyampaikan materi dan tugas terhadap para siswa nya, namun masih 
ada beberapa kendala yang dialami oleh guru maupun siswa seperti tidak semua siswa memiliki handphone yang cukup canggih unuk mengakses aplikasi tersebut dan sering terjadinya kendala sinyal internet yang kurang baik terjadi pada siswa maupun guru. Kendala tersebut mempengaruhi siswa dalam mengikuti pelajaran yang sedang berlangsung, hal tersebut mempengaruhi nilai yang diperoleh para siswa, yang membuat nilai siswa menjadi turun dibandingkan tahuntahun sebelum adanya pandemi Covid19. Faktor lain yang menjadikan nilai turun selain dari terhalangnya handphone dan jaringan internet yaitu terdapat pada kemampuan masingmasing siswa yang berbeda dalam memahami materi yang diberikan oleh para guru selama pembelajaran daring pada masa pandemi Covid-19, dan penurunan nilai para siswa juga terjadi pada kelas X di SMK Ma'arif 9 Kebumen. Hasil dari penelitian ini menyimpulkan bahwa kegiatan pembelajaran daring di SMK Ma'arif 9 Kebumen kurang berjalan dengan lancar karena masih ada siswa yang belum dapat mengikuti kegiatan daring dan kemampuan masing - masing dari siswa yang berbeda dalam memahami materi yang diberikan oleh para guru. Jadi adanya pembelajaran daring selama pandemi Covid-19 ini menjadi factor yang mempengaruhi penurunan rata rata nilai kelas sebesar 3,01\% jika dibandingkan dengan nilai rata-rata kelas sebelum pandemi Covid-19.

Penurunan nilai yang terjadi pada SMK Ma'arif 9 Kebumen dalam masa pandemi Covid-19 ini adalah salah satu contoh bukti nyata bahwa pandemi Covid-19 ini memberikan dampak yang buruk dalam bidang pendidikan. Selain sektor pendidikan masih ada sector lain yang terkena imbas akibat dari Pandemi
Covid-19 seperti sektor perekonomian, sektor kesehatan.

Selama pandemi Covid-19 ini pihak pemerintahan yang bekerjasama dengan lembaga pendidikan terkait sudah melakukan yang terbaik supaya pembelajaran ini tetap berlangsung. Meskipun hasil yang diharapkan tidak terlalu memuaskan, namun itu cukup untuk membuat kegiatan belajar mengajar di Indonesia tetap berlangsung.

Terkait masalah penurunan nilai yang dialami para siswa ini diharapkan supaya memberikan pengaruh terhadap cara guru dalam memberikan materi kepada siswa menjadi lebih baik dan lebih optimal lagi. Membuat materi semenarik mungkin supaya para siswa menjadi semangat dalam belajar dan diharapkan memberikan dampak yang baik meningkatnya lagi nilai para siswa tersebut. Pelaksanaan pembelajaran daring yaitu guru dituntut menjadi lebih inovatif dalam menyusun dan mempersiapkan materi bahan ajar. Dari penelitian ini melaporkan bahwa pembelajaran secara tatap muka lebih baik dari pembelajaran daring. Siswa lebih mudah memahami penyampaian materi yang diberikan dan dijelaskan secara langsung oleh guru. Bahkan pembelajaran daring membuat siswa yang malas menjadi semakin malas. Masih ada siswa yang tidak mengumpulkan tugas padahal jangka waktu yang diberikan panjang dan mudahnya untuk mengakses materi lain di internet. Guru kesulitan mengevaluasi hasil pembelajaran siswa, tidak jarang pengerjaan tugas yang asalasalan karena kurangnya pemahaman materi. Apalagi untuk mata pelajaran yang dianggap sulit oleh siswa seperti Akuntansi maupun Matematika yang menggunakan perhitungan, mereka memerlukan penjelasan materi secara langsung. Akibat dari pembelajaran 
daring ini nilai siswa menjadi turun, pembelajaran daring kurang efektif. Pembelajaran daring dapat dikatakan hanya program dari keputusan akan pemerintah untuk memberantas penularan virus Covid-19. Sedang dalam dunia pendidikan siswa serta guru dipaksa untuk tetap menjalankan proses belajar mengajar di tengah wabah ini. Keterbatasan dari beberapa teknologi pun sangat dirasakan.

Upaya-upaya yang dilakukan guru dalam proses pembelajaran daring adalah guru berusaha mempelajari cara mengoperasikan handphone android,media referensi materi,serta guru berusaha menjaga komunikasi dengan orang tua dan siswa .Dari upaya yang guru lakukan ,upaya yang paling banyak guru lakukan adalah bagaimana guru berusaha menjalin komunikasi antar siswa dan orang tua siswa agar terjadinya kerjasama dalam membimbing siswa. Disamping itu, guru berusaha untuk memotifasi siswa supaya lebih semangat dan giat dalam pembelajaran daring yang sedang berlangsung. Secara umum, permasalahan yang muncul dalam pembelajaran daring merujuk pada keterlibatan siswa terhadap proses pembelajaran daring. Keterlibatan pembelajaran jarak jauh mengacu pada perilaku siswa yang kadang tidak memperhatikan guru ketika guru sedang menjelaskan materi dan ketika memberikan tugas kepada siswa.Ini di pengaruhi olerh faktor dari dalam diri siswa seperti kebutuhan siswa dan faktor luar diri seperti guru yang mengajar (Fredrick et al 2004).

Adapun cara untuk meningkatkan agar pembelajaran daring lebih efektif yaitu:

1. Pihak sekolah memberikan fasilitas kuota maupun wifi kepada guru agar tidak menggunakan dana pribadi guru.

2. Bantuan kuota bagi siswa dan harus diberikan secara rutin setiap bulan selama pembelajaran masih berjalan secara daring.

3. Kesiapan guru dalam mempersiapkan materi supaya menjadi lebih matang.

4. Mengubah cara mengajar guru kepada siswa semenarik mungkin supaya siswa tidak mudah bosan dalam mengikuti kegiatan belajar.

5. Penggunaan aplikasi daring yang mudah diakses oleh siswa.

6. Guru harus memiliki alat perlengkapan pembelajaran online seperti laptop dan alat pendukung video conference.

7. Harus adanya perubahan sistem pembelajaran daring dalam setiap mata pelajaran serta penerapan pembelajaran daring harus sesuai dengan ketersediaan teknologi yang ada.

\section{KESIMPULAN}

Berdasarkan dari hasil penelitian yang telah dilaksanakan, menunjukan bahwa terdapat pengaruh penggunaan media pembelajaran daring terhadap hasil belajar siswa kelas $\mathrm{X}$ di SMK Ma'arif 9 Kebumen.

1. Hasil kesimpulan nilai rata-rata kelas sebelum pandemi adalah 86,92 dan sesudah pandemic menjadi 84,38 sehingga terjadi selisih penurunan sebesar 2,54.

2. Jadi dengan adanya pembelajaran dengan sistem daring akibat adanya pandemi Covid-19 mempengaruhi penurunan rata-rata nilai kelas sebesar $3,01 \%$ jika dibandingkan dengan nilai rata-rata kelas yang diperoleh sebelum pandemi. 


\section{Saran}

a. Sebaiknya pembelajaran daring lebih ditingkatkan lagi dan sarana prasarana harus mendukung agar pembelajaran daring bisa lebih maksimal lagi.

b. Sebaiknya guru memberikan materi atau arahan kepada siswa dalam proses belajar daring

c. Sebaiknya siswa memiliki kesadaran akan tugas yang telah diberikan oleh guru supaya bisa dikerjakan dengan lebih optimal dalam proses pembelajaran daring untuk mendapatkan nilai yang memuaskan.

d. Sebaiknya supaya para guru tidak setiap hari memberikan tugas kepada para siswanya supaya para siswa tidak merasa terbebani dalam belajar melalui system daring.

e. Sebaiknya guru memberikan materi yang lebih menarik lagi supaya para siswa semangat dalam mengikuti pelajaran.

f. Bagi peneliti selanjutnya, hasil penelitian ini bisa digunakan sebagai bahan perbandingan ataupun referensi untuk penelitian, dan sebagai bahan pertimbangan untuk lebih memperdalam penelitan selanjutnya agar hasilnya lebih maksimal.

\section{DAFTAR PUSTAKA}

Darmalaksana, W. (2020). Whatsapp Kuliah Mobile. Fakultas Ushuludin UIN Sunan Gunung Djati Bandung.

Dewi, Laksmi. (2017). Rancangan Program Pembeljaran Daring Di Perguruan Tinggi: Studi Kasus Pada Masa Kuliah Kurikulum Pembelajaran Di Universitas Pendidikan Indonesia. Universitas Pendidikan Indonesia: Edutech, Tahun16, Vol.16, No.2.

Dewi, W. A. F. (2020). Dampak COVID-19
Implementasi Pembelajaran Daring di Sekolah Dasar. Edukatif: Jurnal Ilmu Pendidikan, 2(1), 55-61. https://doi.org/10.31004/edukatif. v2i1.89.

Dzalila,Lizha,Q.A.dkk,(2020).

Pengaruh Pembelajaran Daring Pada Masa Pandemi Covid-19 Terhadap Tingkat Pemahaman Belajar Mahasiswa. $\operatorname{Vol}(8), 2$.

Enceng \& Taher,I. (2006).Hubungan Kemandirian Belajar dan Hasil Belajar pada Pendidikan Jarak Jauh.Jurnal Pendidikan Terbuka dan Jarak Jauh ,7 (2), 91-92.

Gunawan, H. (2017). Dasar-Dasar Metodologi Penelitian Pendidikan. Bandung: Fakultas Tarbiyah Dan Keguruan UIN Sunan Gunung Djati.

Hadisi, La, and Wa Muna. 2015. "Pengelolaan Teknologi Informasi Dalam Menciptakan Model Inovasi Pembelajaran ( ELEARNING )." Jurnal Al-Ta'dib 8(1): 117-40.

Hanum, N. S. (2013). Keefektifan ELearning Sebagai Media Pembelajaran (Studi Evaluasi Model Pembelajaran E-Learning SMK Telkom Sandhy Putra Purwokerto. Yogyakata: Universitas Negri Yogyakarta.

Harnani,Sri.(2020). Efektifitas Pembelajaran Daring di Masa Pandemi Covid-19.

Hartini,S.\& Henilawati (2020) Dampak Pembelajaran Daring Terhadap Hasil Belajar Mahasiswa Intitut Pendidikan Tapanuli Selatan Masa Pandemi Covid-19, 8 (4) https://journal.ipts.ac.id/index.php /ED/article/view/2182.

Hasanah, dkk. (2020). Analisis Aktivitas Belajar Daring Mahasiswa Pada Pandemi Covid-19. Jurnal Pendidikan. Volume 1, No.1. 
Hung, M. L., Chou, C., Chen, C. H., \& Own, Z. Y. (2010). Learner readiness for online learning: Scale development and student perceptions. Computers and Education,55(3), 1080-1090. https://doi.org/10.1016/j.compedu .2010 .05 .004 .

Jamil, S. H., \& Aprilisanda, I. D. (2020). Pengaruh pembelajaran daring terhadap minat belajar mahasiswa pada masa pandemik covid-19. Behavioral Accounting Journal, 3(1), 37-46. https://doi.org/10.33005/baj.v3i1. $\underline{57 .}$

Masrul, dkk. (2020). Pandemi Covid19: Persoalan Dan Refleksi di Indonesia. Medan: Yayasan Kita Menulis.

Putra, M. T. F., Arianti, \& Elbadiansyah. (2019). Analisis Penerapan Model Dan Metode Pembelajaran Tepat. Sebatik, 23, 317-323.

Putra, N. (2013). Metode Penelitian Kualitatif Pendidikan. Rajawali Pers.

Ria, Yunitasari., Umi Hanifah. (2020) Pengaruh, Pembelajaran ,Daring Terhadap Minat Belajar Siswa SD/MI Pada Masa Covid 19 Di Desa Karanggayam Sidoarjo.2 (2).

Saifuddin, M. Fuad.(2017). E-Learning Dalam Presepsi Mahasiswa. Jurnal Varia Pendidikan, Vol. 29, No. 2: 102-109.

Sepita, S. F., \& Suryanti, S. (2020). Pengaruh Pembelajaran Daring Terhadap Hasil Belajar Kognitif Mahasiswa Pada Mata Kuliah Limnologi. Journal of Research and Education Chemistry, 2(2), 102-102.

Shofiyah, Siti. (2016). Pengaruh Penggunaan Android \& Elearning Terhadap Hasil Belajar
Mapel IPS Siswa Kelas VIII SMPN 3 Kepanjen Malang. Malang: UIN Maulana Malik Ibrahim.

Siddiqui, S., \& Singh, T. (2016) Sosial Media Its Impact With Positive And Negative Aspects. International Journal of Computer applications Technology And Research. https://doi.org/10.7753/ijcatr0502. 1006.

Slamento. 2010. Belajar \& Faktor yang Mempengaruhinya. Jakarta: Rineka Cipta.

Sobron, N,A. dkk. (2019). Persepsi Siswa Dalam Studi Pengaruh Daring Learning Terhadap Minat Belajar IPA. SCAFFOLDING: Jurnal Pendidikan Islam dan Multikulturalisme, 1(2), 30-38.

Sobron ,N,A dkk. (2020). Study Pengaruh Daring Learning Terhadap Hasil Belajar Matematika Kelas IV.1 (3)

Sugiyono, (2013). Metode Penelitianm Pendidikan Pendekatan Kuantitatif, Kualitatif dan $R \& D$, Bandung: Alfabeta.

Suharwoto, gogot. (2020). Pembelajaran online ditengah pandemic covid-19. https://pusdatin.kemdikbud.go.id/ pembelajaran-online-di-tengahpandemi-covid-19-tantanganyang-mendewasakan/

Syah, R. H. (2020). Dampak Covid-19 pada Pendidikan di Indonesia: Sekolah,Keterampilan, dan Proses Pembelajaran. SALAM: Jurnal Sosial Dan Budaya SyarI,7(5). https://doi.org/10.15408/sjsbs.v7i $\underline{5.15314 .}$

Syarifah,H.J.Dkk. (2020). Pengaruh Pembelajaran Daring Terhadap Minat Belajar Mahasiswa Pada 
Masa Pandemic Covid-19. Vol.3 No.1.

Trianto. (2015). Model Pembelajaran Terpadu. Jakarta: PT. Bumi Aksara.

Yunitasari. (2020). Pengaruh Pembelajaran Daring Terhadap Minat Belajar Siswa Pada Masa Covid-19. vol 2 no 3.

https://www.dosenpendidikan.co.i d/teknik-pengumpulan-data/ Selasa,12 April,Pukul 20:15.

Yunita,N,W.(2020) penyebab,asal,mula dan pencegahan virus corona di Indonesia $25 \quad$ Maret 2021 https://m.detik.com/news/berita/d4956764/penyebab-asal-muladan-pencegahan-virus-corona-diindonesia. 